\title{
Financing Options and Sustainable Small Business Growth in Uganda: An Optimal Model
}

\author{
Geoffrey Nuwagaba ${ }^{1}$, Festo Nyende ${ }^{2}, \&$ David Namanya ${ }^{2}$ \\ ${ }^{1}$ Department of Accounting and Finance, School of Business, Makerere University, Uganda \\ ${ }^{2}$ Department of Finance and Accounting School of Businesses, College of Businesses and Management Sciences, \\ Makerere University, Uganda \\ Correspondence: Geoffrey Nuwagaba, Department of Accounting and Finance, School of Business, Makerere \\ University, Uganda.
}

Received: July 26, 2021

Accepted: August 27, 2021

Online Published: September 8, 2021

doi:10.5539/ibr.v14n10p85

URL: https://doi.org/10.5539/ibr.v14n10p85

\begin{abstract}
Small businesses in Uganda continue to lag behind trends in terms of sales turnover profitability, employee growth, while others rarely live to celebrate their first birthday due to various constraints of which financing is at the forefront. This study set out to determine the relationship between various financing options and sustainable small business growth so as to suggest an optimal financing model to ensure sustainable small businesses. The study adopted a cross-sectional descriptive survey design to analyse a sample of 399 small businesses which were selected using stratified random sampling from Kampala Metropolitan Area. Data were collected using a researcher administered structured questionnaire and analysed using descriptive statistics. The relationship between the variables was determined using Spearman's rank correlation coefficeint. The study established that there is a weak positive significant correlation between traditional debt finance and sustainable small business growth, a strong positive significant correlation between asset-based finance and sustainable small business growth, and a strong positive significant correlation between crowdfunding and sustainable small business growth. The study further established that there is a moderate positive significant relationship between equity finance and sustainable small business growth. The study concluded that improving on the available financing options would improve on the sustainable small business growth. It is recommended that the ideal model for financing small businesses should be the integration of the financing options, but giving priority to; asset based lending, crowdfunding, equity finance and lastly traditional debt finance.
\end{abstract}

Keywords: financing options, sustainable business growth, small businesses

\section{Background}

Since the 2008-09 global credit crunch, small businesses have faced heightened financing challenges as lending institutions became more stringent with the lending policy for fear of iterating the same scenario (Miller, 2016; Tripathi \& Tripathi, 2018). While small businesses were being prompted to increase their leverage as a strategy for mitigating the effects of crisis, lending institutions in OECD countries on the other hand were being forced to rigorously tighten their lending rules so as to streamline their balance sheets in accordance with prudent accounting rules and regulations through deleveraging(United Nations ESCAP, 2017). As lending institutions proceed with the process of lowering their leverage, small scale businesses on the other hand are grappling with finding the optimal financing solution as traditional bank lending has proved to be costly amidst shrinking revenues hence leading to stagnated sustainability and growth (Organization for Economic Co-operation, (OECD), 2020). Therefore, finding an optimal financing solution for sustainable small scale business growth is a growing concern if they are to continue to playing their important roles in employment, innovation, and economic growth.

Sustainable business growth refers to the business ability to continuously contribute to its profitability while improving the quality of life of the workforce, and protecting the environment where it undertakes its operations (OECD, 2007). A business is sustainable when it embraces 3P's namely; People, Planet, and Profit (Kraaijenbrink, 2019). All these three aspects have to be satisfied before a business venture can be considered sustainable (Naguit, 2018). The first aspect 'people' relates to how a company treats its employees (or human resources) in terms of welfare and ethically, and whether it promotes social cohesion (Kjøde, van der Velden, \& 
Motevallian, 2021).The second aspect 'planet' considers issue of the effect and remedy business operations on natural resources and the landscape. Environmental care, chain management, eco-efficiency, clean products, sustainable technology development, sustainable industry fields and eco-design are concrete examples of these issues(Sharma, Kumar, \& Singh, 2021). The consequence for business behaviour is that either environmental integrity becomes a business goal next to profit seeking(Sharma et al., 2021). The third aspect 'profit' refers to the ability of the business to generate revenues over and above its operating costs and expenses. Profitability is an indicator that the business resources are not put to waste, but are rather efficiently utilised generate value to the business (Scheers, 2016).Often, business profitability is precisely measured as a ratio of total assets commonly referred to as Return on Assets (ROA) or as a ratio of capital employed commonly known as Return on Capital Employed (ROCE)(Dixon, 2019).

While their definition varies from country to country small businesses, small businesses in many countries, range from 5-50 employees in retail operations (Armstrong, 2013). These businesses exist in undertakings such as convenience stores, small grocery stores, bakeries, hairdressing, tradespeople such as electricians, restaurants, guest houses, metal and furniture workshops, photographers, very small scale manufacturing, leisure spots, internet café's, computer mechanics and programming (Edmiston, 2010; Dilger, 2020).

In emerging and developing economies, small businesses constitute over $80 \%$ of all enterprises (Muriithi, 2019; Okumu \& Buyinza, 2020). Small businesses significantly contribute to these economies in terms of employment, innovation and social cohesion, besides being envisaged as a strategy to spur economic progress In Sub-Saharan Africa, small businesses have demonstrated their ability to not only contribute to employment especially of youth and women, but they have also contribute to the growth in domestic gross product (GDP) through multiplying the quantity of goods and services (Hoque, 2016; Diabate, Allate, Wei, \& Yu, 2019). Besides, small businesses have been adopted as a means of redistribution of productive assets in the attempt by governments to close income disparities between the poor and disadvantaged households and the middle class (Rivera-Santos, Holt, Littlewood, \& Kolk, 2015). In the East African region, small businesses reportedly hold the greatest potential of spurring economic growth, entrepreneurship and employment (Gamba, 2019). For instance, in Kenya, small businesses are applauded for their contribution of 50\% of the new jobs that have been created since 2006 (Mwangi, 2016), while in Uganda, small businesses currently provide employment and income to over 2.5 million households(UBOS, 2019; UIA, 2020).

Notwithstanding their importance, sustainable growth of small businesses in Uganda remains a pending question as the majority are retarded in the growth background characterized by stagnated turnover growth accompanied by high cost of capital leading to low profitability, failure to cover operational costs such as rent and less concern for environmental sustainability (Kintu et al., 2019; Wanyana et al., 2019). Ultimately, these businesses fail to sustain their operations on account of inadequate financing or obtaining finance from costly sources that immediately ruin their cash flows making it difficult for them to become profitable, pay employees, meet their cost of operations and environmental sustainability requirements (Buyinza et al., 2018). Therefore, exploring different financing options would enable identification of optimal financing options that are important in enhancing their sustainable growth.

\section{Problem}

While small businesses contribute significantly to national growth, employment, innovation and social cohesion in Uganda, 65\% of these businesses continue to stagnate in the growth background in terms of sales revenues and growth in assets while others fail to sustain their operations for more than a year (Okumu \& Buyinza, 2020). Available evidence attributes this position to costly sources of finance which has lowered their profitability and hence made difficult for them to meet their operational costs and expenses such as payment of employees' wages, rent and become responsible for the physical environment where they are located as they are highly associated with haphazard waste dumping (Buyinza et al., 2018; UIA, 2019). In extreme cases, the assets of these small businesses are seized by lenders over non-payment of loans which leads to their immediate extermination (Ebong, 2019). While there are various financing options for small businesses including traditional debt finance, asset based financing, alternative debt finance, crowdfunding, hybrid instruments and equity instruments (Quartey, Turkson, Abor, \& Iddrisu, 2017), research efforts to determine the optimal financing model for sustainable business growth of small businesses in Uganda are less evident. This study was therefore undertaken to fill this gap.

\section{Objectives}

The general objective of the study was to analyse the relationships between small business financing options and sustainable business growth with the aim of suggesting an optimal financing model for these businesses. To 
attain this objective, the following specific objectives were addressed:

i. $\quad$ To explore different financing options for small businesses in Uganda

ii. To analyse the sustainability of small business growth in Uganda.

iii. To determine the relationships between various financing options and sustainable small business growth.

\section{Literature}

According to OECD (2015), various financing options for small businesses are categorised as traditional debt finance, asset based finance, alternative debt instruments, crowdfunding, hydbrid instruments and equity financing. These financing options are discussed as follows:

Traditional debt finance: The most common forms of traditional bank finance include bank loans, overdrafts, use of credit cards and line of credit lines for financing small scale businesses (Abor \& Biekpe, 2007). A bank loan is the principal amount a bank advances to the individuals or businesses at a fixed interest rate that can be paid either at a reducing balance method or straight line basis depending on lending terms (Demiroglu \& James, 2015). This loan is often for a stipulated time period and within a specified limit depending on the nature of the business and security provided (Schwert, 2020). Common securities provided to secure bank loans include home mortgages, and automobile cards, but advanced businesses can go on to securitize future revenues and cashflows expected from business (Demiroglu \& James, 2015). Although not common with banks, some loans especially to small businesses may not be secured or backed by any collateral, but are often guaranteed (Schwert, 2020). The later option however, attracts much higher interest than for secured loans. Therefore, comparing the two options in light of small business is necessary to determine the alternative that will minimize the overall costs of financing.

An overdraft is a scenario when money is withdrawn from a bank account and the account balance goes below zero amount(Liu, Montgomery, \& Srinivasan, 2018). In this situation the account is said to be "overdrawn" (Alan, Cemalcilar, Karlan, \& Zinman, 2018). Ideally, an overdraft occurs when there is a prior agreement with the account managers and in this case, there is an overdraft limit and an interest will be charged at an agreed rate. However, if the negative balance exceeds the agreed amount, account managers may charge additional fees for the transaction(Alan et al., 2018). A credit card is an instrument that guarantees that the holder's bills will be settled by the card issuer, normally a bank. The process involves the card issuer creating a resolving account from which the card holder can always secure credit for settling the bills (Meier \& Sprenger, 2010). A line of credit is a flexible loan from a bank or any other lending institution. Comparable to a credit card, a line of credit allows the borrower to access a specified amount of money and pay instantly or during a given period of time (Sufi, 2009).

Empirical studies support view that that small banks are correlates of small businesses as regards financing compared to large lending institutions(Donald, 2020). In a survey of SMEs' finance in Japan, Uchida (2011) established that small banks have a tendency to lend to small businesses compared to large banks which require more formal arrangements before loan are processed. Therefore, while lending to small businesses, small banks consider relationships are the most important collateral than high value securities required by larger banks. This in turn eases credit access by small businesses from small size lending institutions. In a related development, Berger and Black (2011) established that small lending institutions have leverage over large ones when it comes to relationship lending, though it is possible that this leverage may be much favourable for larger businesses when credit scoring methodology is adopted. These studies however, do not disclose how these lending methodologies influence the sustainable growth of small businesses.

In Uganda, European Central Bank (2017) reported that traditional banks have been reluctant to finance small scale businesses due to a malfunctioning credit market. The European Central Bank (2017) further indicates that in a bid to avoid tax, small business do not keep adequate records to enable them access formal financing provided by traditional banking institutions. In a related context, Nzibonera and Waggumulizi (2020) established that secured loans for financing working capital have a significant positive relationship with the growth of small scale businesses, but do not indicate the status of lending institutions in terms of size. In addition, the study focused on business growth, while it paid no attention to environmental sustainability (planet). Musoke (2020) established that Small and Medium scale enterprises in Uganda use their savings with Microfinance institutions to secure loans from traditional commercial banks. However, the effect of this financing option on the sustainable growth of these businesses was not substantiated.

Asset based finance: With this process, lenders provide finance to small businesses depending on the ability of 
the asset that is being financed to generate returns. This contrary to traditional debt structuring only requires security without considering returns from the business being financed (OECD, 2015). Typical forms of assets based finance is asset-based lending, factoring and leasing. Asset-based lending (ABL) is form of lending where the security are the returns of that asset that is being financed. The lender overlooks that physical value of the physical assets to consider the subsets or the assets such as the revenues and cash flows that will be generated by the asset since they are the ones that constitute payment (Berger \& Udell, 2006). Factoring provides the supplier with cash from an institution (factor) that considers part of the sales proceeds or accounts receivable for repayment (Bakker, Klapper, \& Udell, 2004). Leasing is commonly associated with financing long terms assets such as equipment, automobiles, and real estates by companies (OECD, 2015). In this regard, the lessor or the person assumes the rights to the asset in agreement until the expiry of the period although he or she may have an option to review the agreement (OECD, 2015). It is however, important to note that the lessor remains the legal owner of the asset throughout the contract (Deloof, Lagaert, \& Verschueren, 2007). Whereas there are various asset based financing mechanisms for small businesses, empirical relationship between these mechanisms and sustainable business growth in Uganda had not been substantiated. This study as well set out to fill this gap.

Alternative debt instruments: With this type of business financing, investors in the financial markets rather than traditional banking institutions provide finance to small businesses. This is done through issuing financial securities such as bonds, stocks and asset securitization (OECD, 2015). While these financing mechanisms have been in operation for quite some time, they are new to most small businesses which may even understand their trading mechanics although they can engage with the aid of brokerage firms (OECD, 2015). While some of these financing instruments such as bonds attract interest on principal, others such as stocks requires issuing common stock implying that providers of finance become shareholders in the business that is being financed which leads to dilution of control (Chen, Cui, He, \& Milbradt, 2018). With securitization, contractual debt are pooled together and sold to investors who acquire rights to receive the cash collected from the financial instruments that underlie the security (OECD, 2013). A lending institution extends a loan to a small business and sells the pooled assets to investors with the aid of an intermediary called a special purpose vehicle (SVP) (SEC, 2013). Literature indicates that alternative debt instruments have been largely adopted in financing SMEs in developed countries. The extent to which these financing instruments have been applied in financing small businesses and their relation with sustainable business growth in developing countries is limited in empirical literature. This study partly filled this gap.

Crowdfunding: Crowd funding is a community based funding technique commonly adopted by businesses that intend to raise funds from large audiences (OECD, 2015). The concept of "crowdfunding" is related to the one of "crowdsourcing", which refers to the outsourcing to the "crowd" of specific tasks, such as the development, evaluation or sale of a product, by way of an open call over the internet (Ahlers, Cumming, Günther, \& Schweizer, 2015). Broadly, crowd funding can take many forms, but majorly including donations, sponsorships and pre-ordering or pre-production agreements after which the borrower will pay the debt after selling the products (Helmer, 2011; Collins \& Pierrakis, 2012). Belleflamme et al. (2011) established that due to the assurance of community experience, crowd funding is a good alternative of funding for small scale businesses. Little however, had remained known about the relationship between these funding option and the sustainable growth of small businesses. This study partly filled this empirical gap.

Hybrid financing instruments: Hybrid financing lies in the middle of the borrowers financing options. Like the name suggests, this financing mechanism integrates equity and debt instruments to the satisfaction of the borrowers' propensity to repay the debt with ease (OECD, 2015). Some of the most commonly used hybrid instruments include: subordinated debt (loans or bonds) whose earning or claims on assets ranks below other loan types; and participation loans, where a business is financed by many lending institutions, but organized by one lead institution(Miller et al., 2016). In the later case, the lead institution is paid first. Other types of hybrid instruments include convertible debt and warrants, and mezzanine finance (Berger \& Udell, 2006). A convertible debt is a scenario where lenders and borrower agree to convert a debt into equity at a later date implying that lenders become shareholders in the borrowing business (Berger \& Udell, 2006). Warrants are equity instrumented entrenched within a mezzanine debt, where the later refers to a debt subordinated to another debt from one issuing institution or individual (Miller et al., 2016). Hybrid instruments are considered most appealing financing mechanisms for small businesses for they provide an opportunity to balance the cost of capital (Miller et al., 2016). However, the extent to which they contribute to the sustainable growth of small businesses has received less attention in empirical literature, and this study partly set out to fill this gap.

Equity finance: Equity finance refers to all financial resources that are provided to firms in return for an ownership stake in the borrowing business (Miller et al., 2016). This implies that providers of finance become 
part of the owners of the business, and hence have to share on the profitability of the business through dividends or stock transfers (Berger \& Udell, 2006). The most common forms of equity finance are venture capital and business angels. Venture capital (VC) often supports pre-establishment of the business or early stages of the business development process (OECD, 2014). Business angels (BAs) on the other hand comprise of high net worth individuals who invest their own funds in a business start-up after which they can secure their returns through floating share on an Initial Public Offering (IPO) and re-invest profits into new businesses (Mason \& Stark, 2004). In Uganda, Lutwama (2015) established that small business have rely on internally generated funds to finance their operations and a few go for traditional loans from commercial banks. Nothing however, is mentioned on how these financing options affect their sustainability. The study further established that these businesses have not ventured into equity financing due to information asymmetry regarding the functioning of this financing option.

Broadly, literature indicates that equity finance is an important source of financing for SMEs. However, private equity is the one most largely adopted by small businesses compared to public equity. While literatures show that public equity finance cannot effectively support the sustainable growth of small businesses due to extreme requirements which these business types may fail to meet, the extent to which private equity fosters sustainable growth for small business is not fully substantiated. This study partly filled this gap.

\section{Methodology}

The study adopted a cross sectional descriptive survey design that employed a quantitative approach. This design is relevant to this study because it systematically and accurately describes the characteristics of large study population at a specific point in time (Creswell \& Creswell, 2018). The study population included small businesses in Kampala Metropolitan Area (Uganda Bureau of Statistics, 2016). This area is composed of the Kampala City and the neighboring districts of Wakiso, Mukono, Mpigi, Buikwe and Luweero. The selection of the study area was justified by the fact that it hosted majority small businesses that were estimated over one million (Uganda Bureau of Statistics, 2019). Data were collected from a sample of 399 small businesses. The study sample was arrived at using Yamane's (1967) formula as follows:

$$
\begin{gathered}
n=\frac{N}{1+N(e)^{2}} \\
\text { Where } \mathrm{n}=\text { required sample size } \\
\mathrm{N}=\text { Population size } \\
\mathrm{e}=\text { Estimation error }=5 \% \text { (Ideal). } \\
\text { Hence } \\
\mathrm{n}=1,000,000 / 1+1,000,000(0.05)^{2} \\
\mathrm{n}=399 \text { respondents. }
\end{gathered}
$$

Stratified random sampling was adopted to select the business that were involved in the study. Each district constituted a stratum from which different businesses were categorized by industry to form a sampling frame after those for inclusion in the sample were selected at random. This allowed inclusion of different business categories in the study sample (Howell, Su, Nassel, Agne, \& Cherrington, 2020). While business owners were the unit inquiry, small businesses will be unit of analysis. Data were collected using a researcher-administered questionnaire. The questionnaire was designed in such manner that it collected data on both the profiles of the business and their owners, in section and data pertaining to the major study variables in another section. While it was structured using nominal scales for capturing profile information, the section of the study variables was structured on a Five point Likert Scale ranging from (1) = strongly disagree, to (5) = strongly agree (Driscoll, 2011).

To ensure data quality, the questionnaire was subjected to validity and reliability tests. Content and constrict validity were determined using content validity index (CVI) and Exploratory factor analysis (EFA) respectively (Delgado-Rico et al., 2012). While the minimum index of 0.7 was considered in computing CVI, only items with factor loadings of at least 0.4 were retained while conducting EFA (Zikmund et al., 2010). Reliability was tested using Cronbach alphas and items that satisfied the threshold coefficient of 0.7 were retained(Drost, 2011; Bhattacharyya, Kaur, Kaur, \& Amaan Ali, 2017). Data were analysed using descriptive statistics (frequencies, percentages, means, and standard deviations), while the Spearman's rank correlation were used to determine the relationship between the non-parametric variables as recommended by (Song \& Park, 2020). Data analysis was 
undertaken with the aid of the statistical Package for Social Sciences (SPSS 26.0).

\section{Results and Discussion}

\section{Business Profile Information}

The profile results were obtained as regard the owners or managers and the nature of the small businesses that were studied. Table 1 provides a summary of the related results.

Table 1. Profiles of owners/managers

\begin{tabular}{lll}
\hline Gender category & Frequency & Percentage \\
Male & 187 & 46.9 \\
Female & 212 & 53.1 \\
Total & 399 & 100.00 \\
Age & Frequency & Percentage \\
$16-25$ years & 64 & 16.0 \\
$26-35$ years & 119 & 29.8 \\
$36-45$ years & 106 & 26.6 \\
$46+$ years & 110 & 27.6 \\
Total & 399 & 100.00 \\
Education level & Frequency & Percentage \\
None & 5 & 1.3 \\
Primary & 104 & 26.1 \\
Secondary & 153 & 38.3 \\
Tertiary & 137 & 34.3 \\
Total & 399 & 100.00 \\
Business experience & Frequency & Percentage \\
Less than 5 years & 181 & 45.4 \\
5-10 years & 168 & 42.1 \\
10+ years & 50 & 12.5 \\
Total & 399 & 100.00 \\
\hline Source: Primary & &
\end{tabular}

Source: Primary data analysis (2021).

The results in Table show that females $(53.1 \%)$ constituted the majority of the respondents than males (46.9\%), while the majority of the participants belonged to age range of 26-46+ years. The results in Table 1 additionally show that on average, the owners/managers of small businesses had attained secondary education, and the most had a business experience of less than five years implying that majority of the owners were new in business.

The profile information was also elicited regarding the nature of small businesses that were studied. The results are provided in Table 2.

Table 2. Business profiles

\begin{tabular}{lll}
\hline Type of business & Frequency & Percentage \\
Agriculture & 44 & 11.0 \\
Small scale manufacturing & 51 & 12.8 \\
Selling finished goods & 155 & 38.8 \\
Services & 149 & 37.3 \\
Total & 399 & 100.00 \\
Geographical location & Frequency & Percentage \\
Buikwe & 59 & 14.8 \\
Kampala city & 92 & 23.1 \\
Mpigi & 80 & 20.1 \\
Mukono & 80 & 20.1 \\
Wakiso & 88 & 22.1 \\
Total & 399 & 100 \\
Length of business existence & Frequency & Percentage \\
$<1$ year & 161 & 40.4 \\
$1-5$ years & 108 & 27.0 \\
$6-10$ years & 89 & 22.3 \\
$>10$ years & 41 & 10.3 \\
Total & 399 & 100.0 \\
Number of employees & Frequency & Percentage \\
$<10$ & 168 & 42.1 \\
$10-20$ & 151 & 37.8 \\
$>20$ & 80 & 20.1 \\
Total & 399 & 100.00 \\
\hline
\end{tabular}

Source: Primary data analysis (2021). 
The results presented in Table 2 portray that most of the small businesses that were studied are involved selling of finished goods and offering services, and almost equally distributed in Kampala metropolitan area with only a difference in distribution in Buikwe district which can be explained by its semi-rural location compared to the rest of the districts. The results in Table 2 further show that most of the businesses were new start-ups as they were in existence for less than a year, a findings that concurs with that of Okumu and Buyinza, (2020) that majority of these businesses do not live for more than a year in operation. Further, the results in Table 2 show that most of the studied businesses had less than 10 employees an indicator of low business growth in terms of the number of employees.

\section{Validity and reliability}

Table 3. Content validity results

\begin{tabular}{llllll}
\hline Variables & $\begin{array}{l}\text { Total Items } \\
\text { Tested }\end{array}$ & $\mathrm{R}$ & $\mathrm{N}$ & $\mathrm{IR}$ & $\mathrm{CVI}$ \\
\hline Traditional bank finance & 4 & 4 & 0 & 0 & 1.000 \\
Asset based finance & 6 & 5 & 2 & 0 & 0.833 \\
Alternative debt instruments & 3 & 3 & 0 & 1 & 1.000 \\
Crowdfunding & 5 & 4 & 0 & 1 & 0.800 \\
Hybrid financing instruments & 6 & 5 & 0 & 1 & 0.800 \\
Equity finance & 3 & 3 & 0 & 0 & 1.000 \\
Sustainable small business growth & 3 & 3 & 0 & 0 & 1.000 \\
\hline
\end{tabular}

Source: Primary data analysis (2021).

The results in Table 3 show all the tested constructs satisfied a minimum of 0.70 index threshold suggested by Waltz, et al. (2005). Therefore, there was sufficient evidence that the measuring instrument contained valid items (Polit \& Beck, 2006).

Table 4. Construct Validity and Reliability Results

\begin{tabular}{|c|c|c|c|}
\hline \multicolumn{4}{|c|}{ Variance explained $=54.7 \%$} \\
\hline Variables & $\begin{array}{l}\text { Total Items } \\
\text { Tested }\end{array}$ & Factor loadings & Cronbach Alphas \\
\hline Traditional debt finance & 4 & 0.590 & 0.752 \\
\hline Asset based finance & 6 & 0.874 & 0.707 \\
\hline Alternative debt instruments & 3 & 0.228 & $\mathrm{n} / \mathrm{a}$ \\
\hline Crowdfunding & 5 & 0.947 & 0.732 \\
\hline Hybrid financing instruments & 6 & 0.282 & $\mathrm{n} / \mathrm{a}$ \\
\hline Equity finance & 3 & 0.590 & 0.790 \\
\hline Sustainable small business growth & 3 & 0.874 & 0.814 \\
\hline
\end{tabular}

Source: Primary data analysis (2021).

As it is observed in Table 4, four of the six items (traditional debt finance, asset based finance, crowdfunding and equity financing) demonstrated factor loadings greater than 0.4. Hence, these four constructs were used to analyse financing options for small scale businesses. Two items (alternative debts instruments and hybrid financing instruments) were discarded from further analysis since they had a factor loading of less than 0.4. The results in Table 4 further indicate that financing options explains $54.7 \%$ of the variance in the data. The results further show that the retained items had a Cronbach's alpha coefficient of more than 0.70 implying that satisfactory evidence of construct validity and reliability for this construct was established.

\section{Descriptive statistics}

Table 5. Descriptive statistics of financing options

\begin{tabular}{lccc}
\hline Financing options & $\mathrm{N}$ & Mean & Standard Deviation \\
\hline Traditional debt finance & 399 & 3.166 & 0.710 \\
Asset based finance & 399 & 4.263 & 0.699 \\
Crowdfunding & 399 & 4.081 & 1.156 \\
Equity finance & 399 & 2.961 & 0.713 \\
\hline Source: Primary
\end{tabular}

Source: Primary data analysis (2021). 
The results in Table 5 show that asset based finance registered the highest mean value of 4.263 . Therefore, the respondents have agreed with the items regarding asset based finance as ideal for financing small businesses. These items are asset based lending, factoring, purchase order finance, warehouse receipts, and leasing. Crowdfunding obtained the second highest mean score of 4.081 implying that the respondents also agreed with items measuring crowdfunding as ideal for financing small businesses. These items include donations, sponsorships, pre-selling or pre-ordering. Traditional debt finance obtained the third highest mean score of 3.166 implying that the respondents agreed with some items while they disagreed with others are ideal for financing small businesses. The items that were agreed with are bank loan, and overdrafts, while those that were disagreed with are a line of credit and credit card. Equity finance obtained a mean score of 2.961 which implies that the respondents were in agreement with some items, while they disagreed with others as ideal for financing small businesses. The items that were agreed with are private equity instruments which include venture capital and business angels, while they disagreed with public equity source of finance.

Table 6. Descriptive statistics of sustainable small business growth

\begin{tabular}{lccc}
\hline & $\mathrm{N}$ & Mean & Std.Dev \\
\hline Sustainable small scale business growth & 399 & 2.989 & 0.436 \\
\hline
\end{tabular}

Source: Primary data analysis (2021)

As can be observed from Table 6, the respondents were neutral with the items used to measure the growth of small businesses. A moderate standard deviation of 0.436 suggests that other respondents moderately deviated from the reported mean value regarding the sustainable growth of small businesses. Hence, the results indicate that respondents were not specific as regards the items that were used to measure sustainable business growth implying that while some had attained sustainable growth, others had not. Statistics in Table 6 further illustrate that some respondents agreed that some small businesses had attained growth in profits, but they all disagreed with growth in employees and improvement in environmental sustainability.

\section{Spearman's Rank Correlations}

Table 7. Spearman's rank correlation results

\begin{tabular}{|c|c|c|c|c|c|}
\hline Variables & 1 & 2 & 3 & 4 & 5 \\
\hline 1. Traditional debt finance & 1.000 & & & & \\
\hline 2. Asset based financing & $0.111^{*}$ & 1.000 & & & \\
\hline 3. Crowdfunding & $0.279 * *$ & 0.141 & 1.000 & & \\
\hline 4. Equity finance & 0.084 & 0.019 & $0.333 * *$ & 1.000 & \\
\hline 5. Sustainable small business growth & $0.376^{*}$ & $0.812 * *$ & $0.519 *$ & $0.412^{*}$ & 1.000 \\
\hline
\end{tabular}

*Significant correlations at 0.05 level.

** Significant correlations at 0.01 level

Source: Primary data analysis (2021).

The results in Table 7 show that there is a weak positive significant correlation between traditional debt finance and sustainable growth of small businesses $(\mathrm{r}=0.376, \mathrm{p}<0.05)$, but a strong positive significant correlation between asset based finance and sustainable growth of small businesses $(r=0.812, p<0.01)$. The results in Table 6 further show that there is a strong positive significant correlation between crowdfunding and sustainable growth of small businesses $(\mathrm{r}=0.519, \mathrm{p}<0.05)$, and a moderate positive significant relationship between equity finance and sustainable growth of small businesses $(r=0.412, \mathrm{p}<0.01)$.

\section{Conclusion and Recommendations}

Building on the results, it is concluded that improving on the financing options would lead to sustainable growth of small businesses in Uganda. Therefore, the optimal financing model of financing small scale businesses to enhance their sustainable growth is the integration of the four funding sources comprising of traditional debt finance, asset based financing, crowdfunding and equity finance. However, owing to the strength of the relationship between the variables, policy makers, implementers and small businesses should give priority to asset based finance items including asset based lending, factoring, purchase order finance, warehouse receipts, and leasing; and crowd funding that should be composed of donations, sponsorships, pre-selling or 
pre-ordering, and lending. Next in line should be equity finance that includes venture capital and business angels, while traditional debt finance should be considered last by small scale businesses vying to attain sustainable growth. Specifically, policy makers such as government should conduct awareness campaigns through seminars and conferences for small businesses owners to understand the advantages of these financing options which will in turn enable small businesses to access them and obtain the required funding. Secondly, policy makers and implementers such as respective government and government agencies should craft and implement policies that enable the establishment of lending institutions with the identified financing vehicles targeting small businesses. The combination of these financing options will keep the cost of finance low while ensuring sustainable small business growth.

\section{References}

Abor, J., \& Biekpe, N. (2007). Small business reliance on bank financing in Ghana. Emerging Markets Finance and Trade, 43(4), 93-102. https://doi.org/10.2753/REE1540-496X430405

Ahlers, G. K. C., Cumming, D., Günther, C., \& Schweizer, D. (2015). Signaling in Equity Crowdfunding. Entrepreneurship: Theory and Practice, 39(4), 955-980. https://doi.org/10.1111/etap.12157

Alan, S., Cemalcilar, M., Karlan, D., \& Zinman, J. (2018). Unshrouding: Evidence from Bank Overdrafts in Turkey. Journal of Finance, 73(2), 481-522. https://doi.org/10.1111/jofi.12593

Bakker, M. H., Klapper, L. F., \& Udell, G. F. (2004). Financing Small and Medium-Size Enterprises with Factoring: Global Growth and Its Potential in Eastern Europe. In The World Bank. https://doi.org/http://ssrn.com/paper=610386

Bhattacharyya, S., Kaur, R., Kaur, S., \& Amaan Ali, S. (2017). Validity and reliability of a questionnaire: a literature review. Chronicles of Dental Research, 6(2), 17-24.

Buyinza, F., Tibaingana, A., \& Mutenyo, J. (2018). Factors Affecting Access to Formal Credit by Micro and Small Enterprises in Uganda. Athens Journal of Business \& Economics, 4(4), 405-424. https://doi.org/https://doi.org/10.30958/ajbe.4-4-4

Chen, H., Cui, R., He, Z., \& Milbradt, K. (2018). Quantifying liquidity and default risks of corporate bonds over the business cycle. Review of Financial Studies, 31(3), 852-897. https://doi.org/10.1093/rfs/hhx107

Creswell, J. W., \& Creswell, J. D. (2018). Research Design: Qualitative,quantititive, and mixed methods approcahes (5th Editio). SAGE Publications, Inc.

Deloof, M., Lagaert, I., \& Verschueren, I. (2007). Leases and debt: Complements or substitutes? Evidence from Belgian SMEs. Journal of Small Business Management, 45(4), 491-500. https://doi.org/10.1111/j.1540-627X.2007.00224.X

Demiroglu, C., \& James, C. (2015). Bank loans and troubled debt restructurings. Journal of Financial Economics, 118(1), 192-210. https://doi.org/10.1016/j.jfineco.2015.01.005

Diabate, A., Allate, B. M., Wei, D., \& Yu, L. (2019). Do Firm and Entrepreneur Characteristics Play a Role in SMEs ' Sustainable Growth in a Middle-Income Economy like $C \hat{o}$ te $d$ ' Ivoire? 11(6), 1-20. https://doi.org/10.3390/su11061557

Dixon, A. D. (2019). Finance and Development. In International Encyclopedia of Geography (pp. 1-8). https://doi.org/10.1002/9781118786352.wbieg0486.pub2

Donald, D. C. (2020). Smart Precision Finance for Small Businesses Funding. European Business Organization Law Review, 21(1), 199-217. https://doi.org/10.1007/s40804-020-00180-1

Drost, E. A. (2011). Validity and Reliability in Social Science Research. Education Research and Perspectives, 38(1), 105-123.

Ebong, C. D. (2019). Government interventions in supporting SME growth in Lira district, northern Uganda. I(February), 107-113.

European Central Bank. (2017). The financing of small and medium-sized enterprises in the euro area. ECB Monthly Bulletin, (August), 75-88.

Gamba, F. J. (2019). SME development policies of Tanzania and Rwanda: comparability of policy presentation on focus, significance, challenges and participation. Journal of Development and Communication Studies, 6(1), 1-17. https://doi.org/10.4314/jdcs.v6i1.1

Hoque, S. S. M. (2016). “ Factors affecting the performance of small and medium enterprises in Factors 
affecting the performance of small and medium enterprises in KwaZulu-Natal, South Africa. https://doi.org/10.21511/ppm.14(2-2).2016.03

Howell, C. R., Su, W., Nassel, A. F., Agne, A. A., \& Cherrington, A. L. (2020). Area based stratified random sampling using geospatial technology in a community-based survey. BMC Public Health, 2(1). https://doi.org/10.1186/s12889-020-09793-0

Jay-Dilger, R. (2020). Small business size standards: Ahistorical analysis of contemporary issues (updated)*. Key Congressional Reports for August 2019: Part VI, 45-103.

Kintu, I., Naluwooza, P., \& Kiwala, Y. (2019). Cash inflow conundrum in Ugandan SMEs : A perspective of ISO certification and firm location. 13(8), 274-282. https://doi.org/10.5897/AJBM2019.8787

Kjøde, S. G., van der Velden, M., \& Motevallian, M. (2021). Article sustainability concepts in nordic business research: A critical perspective. Sustainability (Switzerland), 13(9). https://doi.org/10.3390/su13095160

Kraaijenbrink, J. (2019). What The 3Ps Of The Triple Bottom Line Really Mean. Retrieved from https://www.forbes.com/sites/jeroenkraaijenbrink/2019/12/10/what-the-3ps-of-the-triple-bottom-line-reallymean/\#23dabeb2514

Liu, X., Montgomery, A., \& Srinivasan, K. (2018). Analyzing bank overdraft fees with big data. Marketing Science, 37(6), 855-882. https://doi.org/10.1287/mksc.2018.1106

Lutwama, J. S. (2015). Small \& Medium Enterprises ( SMEs) Financing in Uganda: Are Capital Markets a Viable Option for Small \& Medium Enterprises ( SMEs ) Financing in Uganda? (August 2008), 17.

Meier, S., \& Sprenger, C. (2010). Present-biased preferences and credit card borrowing. American Economic Journal: Applied Economics, 2(1), 193-210. https://doi.org/10.1257/app.2.1.193

Miller, S. M. (2016). Small-Business Financing after the Financial Crisis: Lessons from the Literature. SSRN Electronic Journal, (August). https://doi.org/10.2139/ssrn.2828279

Muriithi, S. (2019). Small And Medium Enterprises ( SMEs ), the Heart of Chinese Small and Medium Enterprises ( SMEs ), The Heart of Chinese Economic Development: What Can African Governments Learn? Journal of Research and Reflection in Management Sciences, 6(3), Retrieved from https://www.researchgate.net/public

Musoke, H. B. (2020). Microfinance Savings Services and the Sustainability of Small and Medium Scale Enterprises. International Journal of Social Sciences and Management Review, 3(6), 168-182. https://doi.org/10.37602/IJSSMR.2020.3523

Mwangi, Z. (2016). The 2016 National Micro, Small and Medium Establishment ( Msme ) Survey. 8-15.

Naguit, M. C. G. (2018). Sustainable entrepreneurship: The triple bottom line and business performance approach. International Journal of Sustainability in Economic, Social, and Cultural Context, 14(3), 51-64. https://doi.org/10.18848/2325-1115/CGP/V14I03/51-64

Nzibonera, E., \& Waggumulizi, I. (2020). Loans and growth of small-scale enterprises in Uganda: A case study of Kampala Central business area. African Journal of Business Management, 14(5), 159-169. https://doi.org/10.5897/ajbm2020.8985

Okumu, I. M., \& Buyinza, F. (2020). Performance of Small and Medium-sized Enterprises in Uganda: The Role of Innovation. Nairobi: The African Economic Research Consortium, Nairobi Kenya.

Quartey, P., Turkson, E., Abor, J. Y., \& Iddrisu, A. M. (2017). Financing the growth of SMEs in Africa: What are the contraints to SME financing within ECOWAS? Review of Development Finance. https://doi.org/10.1016/j.rdf.2017.03.001

Rivera-Santos, M., Holt, D., Littlewood, D., \& Kolk, A. (2015). Social entrepreneurship in sub-saharan Africa. Academy of Management Perspectives, 29(1), 72-91. https://doi.org/10.5465/amp.2013.0128

Scheers, L. van. (2016). How do entrepreneurs measure success in South Africa? Journal of Business and Retail Management Research, 11(1), 1-6.

Schwert, M. (2020). Does Borrowing from Banks Cost More than Borrowing from the Market? Journal of Finance, 75(2), 905-974. https://doi.org/10.1111/jofi.12849

Sharma, D., Kumar, P., \& Singh, R. K. (2021). Modeling Interrelationships of Sustainable Manufacturing Barriers by Using Interpretive Structural Modeling. Lecture Notes in Mechanical Engineering, 211-218. https://doi.org/10.1007/978-981-33-4320-7_19 
Song, H. Y., \& Park, S. (2020). An Analysis of Correlation between Personality and Visiting Place using Spearman's Rank Correlation Coefficient. KSII Transactions on Internet and Information Systems, 14(5), 1951-1966. https://doi.org/10.3837/tiis.2020.05.005

Sufi, A. (2009). Bank lines of credit in corporate finance: An empirical analysis. Review of Financial Studies, 22(3), 1057-1088. https://doi.org/10.1093/revfin/hhm007

Tripathi, V., \& Tripathi, V. (2018). Recent Development of Microfinance in India. SSRN Electronic Journal. https://doi.org/10.2139/ssrn.2462251

UBOS. (2019). Statistical Abstract, 2019. Uganda Bureau of Statistics - Statistical Abstracts, 47, 56. Retrieved from http://www.ubos.org/onlinefiles/uploads/ubos/pdf documents/abstracts/Statistical Abstract 2013.pdf

Uganda Bureau of Statistics. (UBOS). (2016). "National population and housing census 2014-main report," Uganda Bureau of Statistics (UBOS): Kampala, Uganda, 2016.

UIA. (2020). Small and medium enterprises ( SMEs Division). Uganda Investment Authority Brief, 3(10), 3-5.

United Nations ESCAP. (2017). Small and Medium Entreprises Financing. Retrieved from http://www.bnm.gov.my/microsites/rcicc/papers/s6.garciafontes.pdf

Wanyana, B., Murongo, F. M., Mwine, J., \& Wamani, S. (2019). Agro-Related Policy Awareness and Their Influence in Adoption of New Agricultural Technologies ; A Case of Tissue Culture Banana in Uganda. 5, 57-64. https://doi.org/10.32861/jac.55.57.64

\section{Copyrights}

Copyright for this article is retained by the author(s), with first publication rights granted to the journal.

This is an open-access article distributed under the terms and conditions of the Creative Commons Attribution license (http://creativecommons.org/licenses/by/4.0/). 